\title{
A.A. ПЕTPEHKO
}

\author{
Анатолій Анатолійович Петренко, аспірант \\ Інституту держави і права імені В.М. Корецького \\ НАН України*
}

ORCID: 0000-0002-1646-6652

\section{КОНВЕНЦІЙНЕ РЕГУЛЮВАННЯ МІЖНАРОДНОГО СПІВРОБІТНИЦТВА B PAMKAX OECP}

\begin{abstract}
Характерною тенденцією розвитку міжнародного права у другій половині XX та на початку XXI ст. є суттєве розширення правотворчої функції міжнародних міжурядових організацій. Міжнародні організації як суб'єкти міжнародного права займають важливе місце у вирішенні спільних питань у політичній, економічній, соціальній, освітній та інших сферах, діючи від імені та в інтересах держав і урядів, які їх створили. Аналізуючи роль міжнародних організацій в процесі міжнародної правотворчості, відомий польський юрист-міжнародник К. Скубішевський свого часу слушно зауважував, що «ця роль виражається у різних формах починаючи від простих підготовчих та допоміжних дій, які допомагають державам краще укладати договори у все зростаючій кількості сфер або прийняття незобов'язуючих резолюцій, що стосуються міжнародного права, до участі як сторони у деяких договорах та прийняття різних видів регулювання, включаючи правила, які прямо зобов’язують держави та замінюють договори»1.

У системі міжнародних організацій економічного характеру, які у своїй діяльності охоплюють широке коло проблем та напрямів, важливе місце належить Організації економічного співробітництва та розвитку (Organisation for Economic Cooperation and Development (OECD)). Ця організація була утворена у 1961 р. на базі Європейської організації економічного співробітництва, заснованої у 1948 р. в якості інституційної структури для ефективного використання американської допомоги з метою реконструкції Свропи після Другої Світової війни в рамках Плану Маршала. Первинними членами цієї організації стали промислово розвинуті країни Свропи та Північної Америки, згодом ця організація еволюціонувала у своєрідний «клуб» найбільш промислово розвинутих країн світу. Нині до складу ОЕСР входять 36 держав-учасниць: Австралія, Австрія, Бельгія, Великобританія, Греція, Данія, Естонія, Ізраїль, Іспанія, Ісландія, Ірландія, Італія, Канада, Корея, Латвія, Литва, Люксембург, Мексика, Німеччина, Норвегія, Нова Зеландія, Нідерланди, Польща, Португалія, Словаччина, Словенія, США, Туреччина, Угорщина, Фінляндія, Франція, Чехія, Чилі, Швейцарія, Швеція, Японія.
\end{abstract}

Характеризуючи вплив діяльності ОЕСР на прогресивний розвиток сучасного міжнародного права, слід зауважити, що протягом майже 70 років існування ОЕСР в рамках цієї організації було розроблено та прийнято чимало різноманітних правових інструментів, спрямованих на вирішення найширшого кола питань, пов'язаних 3 різними сферами економіки, боротьбою з корупцією, освітою і наукою, охороною навколишнього середовища тощо, а саме рішення, рекомендації, декларації, міжнародні договори, ad hoc інструменти. «В ОЕСР ми встановлюємо міжнародні правила. Члени ОЕСР можуть обрати чи бажають вони перетворити їх в обов'язкові угоди. Але оскільки немає єдиного органу, який би встановлював правила в міжнародному праві, багатьох технічних необов'язкових стандартів ОЕСР дотримуються так, якби вони були обов'язковими»², - зауважував Генеральний секретар OECP Хосе Ангель Гуріа у своєму виступі на щорічному зібранні Американської асоціації міжнародного права у 2011 р.

Попри таку суттєву роль, яку відіграє ОЕСР у міжнародному правотворчому процесі, дослідження правотворчої функції та й загалом міжнародно-правового статусу ОЕСР тривалий час майже не привертало уваги вітчизняних юристів-міжнародників. Можна вказати лише на дисертаційне дослідження 3 та низку публікацій ${ }^{4}$ української дослідниці В.П. Тичини. Питання міжнародно-правового співробітництва у сфері захисту економічної конкуренції в рамках ОЕСР досліджував Ю.І. Зайченко 5 , антикорупційні інструменти ОЕСР I.C. Ніжинська 6 . У зарубіжній науці проблематика, пов'язана з впливом ОЕСР на розвиток міжнародного права, також не належить до найбільш популярних, проте ці питання розглядалися у працях таких науковців,

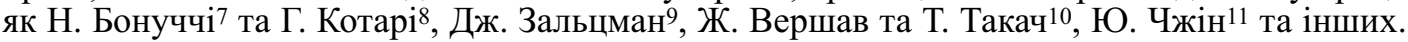

Метою даної публікації є аналіз юридичного змісту та ефективності міжнародних договорів, розроблених та прийнятих під егідою ОЕСР.

Варто зауважити, що якщо виходити суто з кількісного показника, то юридично обов'язковим міжнародним договорам належить порівняно невеликий відсоток у всьому нормативному масиві актів, прийнятих в рамках ОЕСР. Протягом усього періоду існування цієї міжнародної міжурядової організації в ії рамках прийнято 13 конвенцій, 10 я яких є чинними на сьогоднішній день (Конвенція про встановлення безпекового контролю в сфері ядерної енергії від грудня 1957 р. ${ }^{12}$, Конвенція про відповідальність перед третьою стороною в сфері ядерної енергії від 29 липня 1960 р. ${ }^{13}$, відома як Паризька конвенція 1960 р., Конвенція від

(C) А.А. Петренко, 2020

* Anatolii Petrenko, Postgraduate student of V. M. Koretsky Institute of State and Law of the NAS of Ukraine 
31 січня 1963 р., що доповнює Паризьку конвенцію від 29 липня 1960 р. ${ }^{14}$, або Додаткова Брюссельська конвенція, Конвенція про взаємну адміністративну допомогу у податкових справах від 25 січня 1988 p..$^{15}$ та Протокол про внесення доповнень до неї від 27 травня 2010 р. ${ }^{16}$, Конвенція про боротьбу з підкупом посадових осіб іноземних держав при міжнародних ділових операціях від 17 грудня 1997 p. ${ }^{17}$, Рамкова угода про багатосторонню ядерно-екологічну програму в Російській Федерації (MNEPR) від 21 травня 2003 р.18 та Протокол щодо претензій, судового розгляду та відшкодування шкоди до неї19, Рамкова угода про міжнародне співробітництво $з$ досліджень та розробок систем ядерної енергетики IV покоління від 28 лютого 2005 р. ${ }^{20}$, Багатостороння конвенція про виконання заходів, які стосуються угод про оподаткування, з метою протидії розмиванню бази оподаткування та виведенню прибутку з-під оподаткування від 24 листопада 2016 р.21), дві 3 них не набули чинності (Угода про створення фонду фінансової підтримки ОЕСР від 9 квітня 1975 р.22 та Угода про нормальні умови конкуренції у комерційній суднобудівній та ремонтній галузі від 21 грудня 1994 р.23), одна втратила свою юридичну силу (Свропейська валютна угода від 29 липня 1955 р.24).

Провідне місце серед прийнятих під егідою ОЕСР міжнародних конвенцій займає Конвенція про боротьбу з підкупом посадових осіб іноземних держав при міжнародних ділових операціях від 17 грудня 1997 р., яка набула юридичної сили 15 лютого 1999 р. відповідно до положень ст. 15, що передбачає наступну умову набуття чинності цим міжнародно-правовим документом: необхідно, щоб п’ять 3 десяти держав, що мають найбільшу частку в обсязі експорту відповідно до додатку до конвенції (США, Німеччина, Японія, Франція, Велика Британія, Італія, Канада, Південна Корея, Нідерланди, Бельгія разом з Люксембургом) та представляють не менше ніж 60 \% комбінованого сумарного експорту цих десяти держав, депонували документи про затвердження, прийняття чи ратифікацію конвенції. Відповідно до ст. 13 конвенція є відкритою для приєднання не тільки держав-членів ОЕСР, а й будь-якої держави, що стала повноправною учасницею Робочої групи з питань хабарництва в міжнародних ділових операціях. Станом на 2020 р. у ній беруть участь 44 держави - всі держави-члени ОЕСР, а також Аргентина, Болгарія, Бразилія, Колумбія, Коста-Ріка, Перу, Російська Федерація та Південноафриканська Республіка.

Відповідно до положень ст. 1 цієї конвенції кожна держава-учасниця вживатиме всіх необхідних заходів для того, щоб встановити, що відповідно до національного законодавства свідома пропозиція, обіцянка або надання прямо або через посередників будь-яких матеріальних, грошових чи інших переваг з боку будь-якої юридичної або фізичної особи на користь посадових осіб іноземних держав, або для таких посадових осіб, або для третіх осіб в обмін на певні дії або бездіяльність цієї посадової особи в зв'язку з виконанням своїх службових обов'язків і з метою отримання або збереження ділової вигоди, а також отримання неналежних переваг при здійсненні міжнародних ділових операцій утворює склад кримінально караного злочину 25 . Пункт 2 цієї ж статті криміналізує також співучасть, підбурювання, сприяння і пособництво та санкціонування дій, спрямованих на підкуп посадової особи іноземної держави. Українська дослідниця I.С. Ніжинська справедливо наголошує, що однією з цілей цього документа $є$ «підвищення ролі урядів у запобіганні випадків вимагання хабарів від окремих осіб та компаній при здійсненні міжнародних ділових операцій» 26 . Конвенція регламентує питання санкцій, передбачаючи у ст. 3, що підкуп посадової особи іноземної держави підлягає ефективному, співрозмірному та суворому кримінальному покаранню, здійснення юрисдикції щодо такого роду злочинів (ст. 4), вжиття заходів щодо унеможливлення створення прихованих рахунків та укладення неврахованих або сумнівних угод, запису неіснуючих витрат з метою підкупу посадових осіб іноземної держави (ст. 8), надання взаємної правової допомоги в інтересах кримінального розслідування та судового переслідування щодо правопорушень, що охоплюються конвенцією (ст. 9), видачі злочинців (ст. 10), здійснення поточного контролю та сприяння повній реалізації конвенційних положень (ст. 12) тощо.

Аналізуючи конвенційні механізми ОЕСР доречно виділити групу конвенцій, які стосуються гармонізації та урегулювання податкового законодавства, зокрема Конвенцію про взаємну адміністративну допомогу у податкових справах від 25 січня 1988 р. (набула чинності 1 квітня 1995 р.) та Протокол про внесення доповнень до неї від 27 травня 2010 р. (набув чинності 1 червня 2011 р.), а також Багатосторонню конвенцію про виконання заходів, які стосуються угод про оподаткування, з метою протидії розмиванню бази оподаткування та виведенню прибутку з-під оподаткування від 24 листопада 2016 р. (набула чинності 1 липня 2018 р.).3 нашої точки зору, «податкові» конвенції ОЕСР можуть бути визнані найбільш вдалим прикладом діяльності з кодифікації та прогресивного розвитку міжнародного права, що здійснювалася під егідою цієї організації. Якщо Конвенція про взаємну адміністративну допомогу у податкових справах 1988 р., яка розроблялася ОЕСР спільно з Радою Європи, була відкрита для підписання лише для держав-членів ОЕСР та Ради Європи, то версія цієї конвенції в редакції Протоколу 2010 р. відкрита для підписання для будь-якої держави. Відповідно до ст. 28 Конвенції в редакції Протоколу 2010 р. держава, яка не є членом ОЕСР чи Ради Європи, може робити запит, щоб ій запропонували підписати та ратифікувати Конвенцію, а відповідне рішення щодо запрошення такої держави приймається сторонами Конвенції шляхом досягнення консенсусу через координаційний орган. Станом на 2020 р. в цьому документі брали участь 108 держав, в тому числі й Україна27. Багатостороння конвенція про виконання заходів, які стосуються угод про оподаткування, з метою протидії розмиванню бази оподаткування та виведенню прибутку з-під оподаткування 2016 р. відповідно до ст. 27 відкрита для підписання всіма державами і станом на 2020 р. вона вже набула чинності для 43 держав, в тому числі і України, а також для трьох коронних володінь британської корони - Джерсі, Гернсі та Мен, а загальна кількість підписантів цього документа перевищує 90 держав та юрисдикцій ${ }^{28}$.

Предметом регулювання Конвенції про взаємну адміністративну допомогу у податкових справах 1988 р. є надання державами, що беруть у ній участь, адміністративної допомоги в сфері оподаткування. Ця допомога може включати при необхідності дії, що здійснюються судовими органами. Відповідно до положень ст. 1 цього документа така допомога включає: обмін інформацією, у тому числі одночасні податкові 
перевірки і участь у податкових перевірках за кордоном; стягнення заборгованості щодо сплати податків, включаючи захисні заходи; вручення документів. Держави-учасниці Конвенції надають адміністративну допомогу одна одній незалежно від того, чи є особа, яка зачіпається відповідними положеннями, резидентом або громадянином цієї сторони або будь-якої іншої держави ${ }^{29}$.

У свою чергу, Багатостороння конвенція про виконання заходів, які стосуються угод про оподаткування, 3 метою протидії розмиванню бази оподаткування та виведенню прибутку 3-під оподаткування 2016 р. стала результатом реалізації так званого «Плану BEPS» (Base Erosion and Profit Shifting), що був розроблений ОЕСР разом з Групою двадцяти і мав своєю метою протидію агресивному міжнародному податковому плануванню, спрямованому на штучне виведення прибутків 3-під оподаткування до юрисдикцій з низьким або нульовим рівнем оподаткування. Цей документ передбачає заходи, спрямовані на запобігання застосуванню гібридних схем зменшення податкового навантаження (ч. 2), зловживання положеннями угод про уникнення подвійного оподаткування (ч. 3), штучного уникнення статусу постійного представництва (ч. 4). Конвенція $\epsilon$ ефективним способом одночасної зміни значної кількості угод про уникнення подвійного оподаткування, в той же час зберігаючи за державами-учасницями право самостійно визначати, які саме угоди вона бажає змінити.

Ще одним важливим напрямом міжнародно-правового співробітництва держав у рамках ОЕСР, з якого власне і починалася діяльність цієї організації з прийняття міжнародних конвенцій, стала розробка конвенцій у сфері правового забезпечення питань ядерної безпеки, відповідальності за шкоду, спричинену ядерними інцидентами, розвитку та використанню ядерної енергії, у тому числі поводження з радіоактивними відходами, що знайшло своє відображення в Конвенції про встановлення безпекового контролю у сфері ядерної енергіï 1957 р. (набула чинності 22 липня 1959 р.), Паризькій конвенції 1960 р. (набула чинності 1 квітня 1968 р.),Додатковій Брюссельській конвенції 1963 р. (набула чинності 4 грудня 1974 р.), Рамковій угоді про міжнародне співробітництво 3 досліджень та розробок систем ядерної енергетики IV покоління 2005 р. (набула чинності 28 лютого 2005 р.). Значення діяльності ОЕСР для кодифікації і прогресивного розвитку норм міжнародного права, що регламентують питання використання ядерної енергії та відповідальності за ядерну шкоду, полягає в тому, що саме під егідою цієї організації були ще у кінці 50-х - на початку 60-х рр. минулого століття прийняті перші юридично зобов'язуючи документи в цій сфері, а сформульовані в них принципи, зокрема абсолютної відповідальності оператора ядерної установки, були покладені в основу конвенцій, прийнятих під егідою МАГАТЕ (Віденська конвенція про цивільну відповідальність за ядерну шкоду 1963 р.). Паризька конвенція 1960 р., яка доповнювалася трьома протоколами від 28 січня 1964 р., 16 листопада 1982 р. та 12 лютого 2004 р. (не набув чинності), відкрита для приєднання тільки для держав-членів OECP, а для інших держав лише за умови одноголосної згоди договірних сторін, нараховує на 2020 р. 15 держав-учасниць, всі з яких є членами ОЕСР 30 . Стороною Додаткової Брюссельської конвенції може стати лише держава, яка бере участь у Паризькій конвенції 1960 р. Станом на 2020 р. 12 держав-учасниць ОЕСР брали участь у цьому міжнародно-правовому документі 31.

Отже, розглядаючи конвенційний вимір реалізації правотворчої функції ОЕСР, можна зробити висновок, що попри порівняно невелику кількість договірних інструментів, розроблених та прийнятих під егідою цієї організації, вони відіграють досить вагому роль у системі сучасного міжнародного права. Адже міжнародні договори, укладені в рамках ОЕСР, спрямовані на вдосконалення правового регулювання міждержавних відносин в основних напрямах діяльності ОЕСР, зокрема в податковій, антикорупційній сферах та в сфері ядерної енергетики, характеризуються високим рівнем юридичної техніки. Більше того, ряд конвенцій ОЕСР є відкритими для приєднання для будь-якої держави світу, що дозволяє навіть державам, які не є членами ОЕСР, користуватися перевагами міжнародно-правового співробітництва в рамках цієї організації провідних промислово розвинутих держав світу. Так, наприклад, Україна приєдналася до Конвенції про взаємну адміністративну допомогу в податкових справах 1988 р. в редакції Протоколу 2010 р. та Багатосторонньої конвенції про виконання заходів, які стосуються угод про оподаткування, з метою протидії розмиванню бази оподаткування та виведенню прибутку з-під оподаткування 2016 р.

${ }^{1}$ Skubiszewski K. Forms of Participation of International Organizations in the Lawmaking Processes. International Organization. Vol. 18. № 4 (Autumn 1964). P. 804.

2 Harmony and dissonance in international law. Remarks by Angel Gurría, OECD Secretary-General, delivered at the annual meeting of the American Society of International Law, Washington D.C. 25 March 2011. URL: https:/www.oecd.org/unitedstates/har monyanddissonanceininternationallaw.htm

3 Тичина В.П. Міжнародно-правовий статус організації економічного співробітництва та розвитку: автореф. дис. ... канд. юрид. наук: 12.00.11; Нац. юрид. ун-т ім. Ярослава Мудрого. Харків, 2019. $20 \mathrm{c.}$

4 Тичина В.П. Міжнародна правосуб'єктність Організації економічного співробітництва та розвитку. Науковий вісник Ужгородського національного університету. 2017. Вип. 46. Т. 2. С. 166-170 (Серія «Право»); Тичина В.П. Правова характеристика рекомендацій Організації економічного співробітництва та розвитку. Науковий вісник Міжнародного гуманітарного університету. 2017. № 26. С. 123-126 (Серія «Юриспруденція»).

5 Зайченко Ю.І. Роль Організації економічного співробітництва та розвитку у захисті економічної конкуренції на міжнародному рівні. Прикарпатський юридичний вісник. 2016. Вип. 2. С. 136-139.

6 Ніжинська I.C. Міжнародні конвенції як засіб боротьби з корупцією. Наше право. 2013. № 12. С. 174-179.

7 Bonucci N. The OECD at Fifty: Some Observations on the Evolving Nature of an International Organization. The George Washington International Law Review. 2011. Vol. 43. № 2. P. 239-254.

8 Bonucci N., Kothari G. Organization for Economic Cooperation and Development (OECD). Max Planck Encyclopedia of Public International Law [MPEPIL]. Oxford Public International Law. URL: https://opil.ouplaw.com/view/10.1093/law:epil/ 9780199231690/law-9780199231690-e663 


\section{Правова система України й міжнародне право, порівняльне правознавство}

9 Salzman J. The Organization for Economic Cooperation and Development's Role in International Law. George Washington International Law Review. 2011. Vol. 43. № 2. P. 255-276.

10 Verschaeve J., TakácsT. The EU's International Identity: The Curious Case of the OECD.The European Union's emerging international identity: views from the global arena. Edited by Dewaele H. and Kuipers J.-J. Leiden; Boston: Martinus Nijhoff, 2013. P. $187-209$.

11 Чжин Ю. Международно-правовые вопросы деятельности Организации экономического сотрудничества и развития: автореф. дис. ... канд. юрид. наук: 12.00.10; Российский университет дружбы народов. Москва, 2000. 16 с.

12 Convention on the Establishment of a Security Control in the Field of Nuclear Energy. URL: https://legalinstruments.oecd. org/en/instruments/OECD-LEGAL-0020

13 Convention on Third Party Liability in the Field of Nuclear Energy. URL: https://legalinstruments.oecd.org/en/instruments/ OECD-LEGAL-0038

14 Convention of 31 January 1963 Supplementary to the Paris Convention of 29 July 1960. URL: https://legalinstruments.oecd. org/en/instruments/OECD-LEGAL-0053

15 Convention on Mutual Administrative Assistance in Tax Matters. URL: https://legalinstruments.oecd.org/en/instruments/ OECD-LEGAL-0235

16 Protocol amending the Convention on Mutual Administrative Assistance in Tax Matters. URL: https://legalinstruments.oecd. org/en/instruments/OECD-LEGAL-0382

${ }^{17}$ Convention on Combating Bribery of Foreign Public Officials in International Business Transactions. URL: https://legalinstruments.oecd.org/en/instruments/OECD-LEGAL-0293

18 Framework Agreement on a Multilateral Nuclear Environmental Programme in the Russian Federation (MNEPR). URL: https://legalinstruments.oecd.org/en/instruments/OECD-LEGAL-0314

19 Protocol on Claims, Legal Proceedings and Indemnification to the Framework Agreement on a Multilateral Nuclear Environmental Programme in the Russian Federation (MNEPR). URL: https://legalinstruments.oecd.org/en/instruments/OECD-LEGAL-0315

20 Framework Agreement for International Collaboration on Research and Development of Generation IV Nuclear Energy Systems. URL: https://legalinstruments.oecd.org/en/instruments/OECD-LEGAL-0332

${ }^{21}$ Multilateral Convention to Implement Tax Treaty Related Measures to Prevent Base Erosion and Profit Shifting. URL: https://legalinstruments.oecd.org/en/instruments/OECD-LEGAL-0432

22 Agreement Establishing a Financial Support Fund of the Organisation Economic Co-operation and Development. URL: https://legalinstruments.oecd.org/en/instruments/OECD-LEGAL-0136

23 Agreement respecting Normal Competitive Conditions in the Commercial Shipbuilding and Repair Industry. URL: https://legalinstruments.oecd.org/en/instruments/OECD-LEGAL-0277

24 European Monetary Agreement.URL:https://legalinstruments.oecd.org/en/instruments/OECD-LEGAL-0010

25 Convention on Combating Bribery of Foreign Public Officials in International Business Transactions. URL: https://legalinstru ments.oecd.org/en/instruments/OECD-LEGAL-0293

26 Ніжинська І.С. Міжнародні конвенції як засіб боротьби з корупцією. Наше право. 2013. № 12. С. 177.

27 Jurisdictions Participating in the Convention on Mutual Administrative Assistance in Tax Matter Status - 20 February 2020. URL: http://www.oecd.org/tax/exchange-of-tax-information/Status of convention.pdf

28 Signatories and Parties to the Multilateral Convention to Implement Tax Treaty Related Measures to Prevent Base Erosion and Profit Shifting. Status as of 13 May 2020. URL: http://www.oecd.org/tax/treaties/beps-mli-signatories-and-parties.pdf

29 Convention on Mutual Administrative Assistance in Tax Matters. URL: https://legalinstruments.oecd.org/en/instruments/ OECD-LEGAL-0235

30 Paris Convention on Nuclear Third Party Liability. Latest status of ratifications or accessions. URL: http://www.oecd-nea.org/ law/paris-convention-ratification.html

${ }^{31}$ Brussels Supplementary Convention. Latest status of ratifications or accessions. URL: http://www.oecd-nea.org/law/brusselsconvention-ratification.html

\section{Резюме}

Петренко А.A. Конвенційне регулювання міжнародного співробітництва в рамках ОЕСР.
У даній статті досліджуються місце та роль багатосторонніх конвенцій, прийнятих під егідою ОЕСР, в системі сучасного міжнародного права. Показано, що попри порівняно невелику кількість, конвенції, розроблені під егідою ОЕСР, $є$ досить вдалими прикладами кодифікації і прогресивного розвитку міжнародного права в сфері боротьби з корупцією, адміністративної допомоги в сфері оподаткування, протидії розмиванню бази оподаткування та виведенню прибутку з-під оподаткування, а також ядерної безпеки, відповідальності за шкоду, спричинену ядерними інцидентами.

Ключові слова: Організація економічного співробітництва та розвитку (ОЕСР), правотворча функція ОЕСР, кодифікації та прогресивний розвиток міжнародного права, Конвенція про взаємну адміністративну допомогу у податкових справах 1988 р., Конвенція про боротьбу з підкупом посадових осіб іноземних держав при міжнародних ділових операціях 1997 р.

\section{Резюме}

\section{Петренко А.А. Конвенционное регулирование международного сотрудничества в рамках ОЭСР.}

В данной статье исследуются место и роль многосторонних конвенций, принятых под эгидой ОЭСР, в системе современного международного права. Показано, что, несмотря на сравнительно небольшое количество конвенции, разработанные под эгидой ОЭСР, являются достаточно удачными примерами кодификации и прогрессивного развития международного права в сфере борьбы с коррупцией, административной помощи в области налогообложения, противодействия размыванию базы налогообложения и выведения прибыли из-под налогообложения, а также ядерной безопасности, ответственности за ущерб, причиненный ядерными инцидентами.

Ключевые слова: Организация экономического сотрудничества и развития (ОЭСР), правотворческая функция ОЭСР, кодификация и прогрессивное развитие международного права, Конвенция о взаимной административной помощи в налоговых вопросах 1988 г., Конвенция о борьбе с подкупом должностных лиц иностранных государств при международных деловых операциях 1997 г. 
Summary

Anatolii Petrenko. Conventional Regulation of International Cooperation within OECD.

A characteristic trend in the development of international law in the second half of the XX century and early XXI century is the significant expansion of the law-making function of international intergovernmental organizations, which are obtaining an increasingly important role each year in resolving common issues in the political, economic, social, educational and other spheres, acting on behalf and in the interests of the states that formed them. In the system of international organizations of economic nature, an important place belongs to the Organization for Economic Cooperation and Development, which unites 36 industrialized countries as at 2020. During almost 70 years of the OECD existence, the organization has developed and adopted a wide variety of legal instruments aimed at addressing the widest range of issues related to various sectors of the economy, the fight against corruption, education and science, the environment, etc., recommendations, declarations, international agreements, ad hoc instruments. Based on a purely quantitative indicator, legally binding international treaties have a relatively small percentage of the entire normative body of acts adopted under the OECD. In total, 13 conventions were adopted within its framework, 10 of which are in force today. However, the conventions, developed under the aegis of the OECD, are quite successful examples of codification and progressive development of international law in the fields of: anti-corruption (Convention to Combat Bribery of Foreign Officials in International Business Transactions of December 17, 1997); administrative assistance in the field of taxation (Convention on Mutual Administrative Assistance in Tax Matters of January 25, 1988 and Protocol amending the Convention on Mutual Administrative Assistance in Tax Matters of May 27, 2010); counteraction to the tax base erosion and profit shift (Multilateral Convention to Implement Tax Treaty Related Measures to Prevent Base Erosion and Profit Shifting of November 24, 2016); nuclear safety, liability for damage caused by nuclear incidents (Convention on the Establishment of a Security Control in the Field of Nuclear Energy of December 20, 1957, Convention on Third Party Liability in the Field of Nuclear Energy of July 29, 1960 (Paris Convention, 1960), Convention of 31 January 1963 Supplementary to the Paris Convention of July 29, 1960 (Brussels Supplementary Convention).

Key words: Organization for Economic Cooperation and Development (OECD), law-making function of OECD, codification and progressive development of international law, Convention on Mutual Administrative Assistance in Tax Matters of 1988, convention to Combat Bribery of Foreign Officials in International Business Transactions of 1997.

DOI: 10.36695/2219-5521.2.2020.94

УДК 341

\section{А. ПОЛАДОВ}

Араз Поладов, докторант Бакинского государственного университета*

\section{ПРАВИЛА ЗАЩИТЫ ПЕРСОНАЛЬНЫХ ДАННЫХ В ПРАВОВОЙ СИСТЕМЕ США}

Постановка проблемы и ее актуальность. В формировании и развитии права на неприкосновенность частной жизни в Соединенных Штатах Америки в современном понимании решающую роль сыграл доктринальный поход, в частности, знаменитая статья «Право на личную жизни», опубликованная 15 декабря 1890 г. в «Гарвардском юридическом обозрении» С.Д. Уоррена и Л. Брандейса. С точки зрения неприкосновенности частной жизни статья определила направление развития законодательства США. Более того, это был главный прогрессивный шаг для дальнейшего развития этого права как в странах Англосаксонской, так и в странах Континентальной правовой системы. Хотя в статье указывается, что это право уже существовало во Франции и соответственно, должно быть признано в Соединенных Штатах Америки, статья фокусируется на различиях в методологических подходах к этому закону в странах с системами континентального и общего права.

В Конституции США нет конкретной статьи о неприкосновенности частной жизни, однако деятельность судов выявила конституционные основы защиты частных прав от произвольного вмешательства в некоторые конфиденциальные области частной жизни. Она основана на защите индивидуальных свобод от вмешательства государства, и это закреплено в четвертой, пятнадцатой и четырнадцатой поправках к Конституции.

Целью статьи является определение общей характеристики защиты персональных данных: анализ законодательства и прецедентного права.

Анализ исследований и публикаций. В доктрине и прецедентном праве обоснование необходимости нормативно-правового закрепления защиты персональных данных рассматривается в работах Н. Терри ${ }^{7}$, Л. Сотто 6 , С. Ходжес ${ }^{5}$, М.У. Бреннан ${ }^{2}$, Ф.С. Члаповски ${ }^{4}$ и др.

Изложение основного материала. В целом в Соединенных Штатах Америки существует отраслевой подход к конфиденциальности данных. Нет специального федерального закона, который гарантировал бы конфиденциальность и защиту персональных данных. Вместо этого законодательство на федеральном уровне в первую очередь защищает данные в определенных секторах. В отличие от Общего Регламента ЕС, в Соединенных Штатах Америки действуют федеральные законы и законы штатов, административные и

(C) А. Поладов, 2020

* Araz Poladov, Ph.D. Candidate of Baku State University 